\title{
Ideas for Designing and Implementing Portfolios for Short-Term Study Abroad
}

\section{Tomoka Kaneko \\ Nishogakusha University}

\section{Reference Data:}

Kaneko, T. (2020). Ideas for designing and implementing portfolios for short-term study abroad. In P. Clements, A. Krause, \& R. Gentry (Eds.), Teacher efficacy, learner agency. Tokyo: JALT. https://doi.org/10.37546/JALTPCP2019-27

This paper describes how I designed and implemented a portfolio project in a short-term studyabroad program at my university in Japan. Sixteen EFL students participated, and of these, none had experience of producing portfolios before the study. I planned the project based on an analysis of the program and students. Central to the portfolio was a reflective report, designed to help the students reflect on what they learned and to set goals based on reflection throughout the program. The students received instructions on how to complete the portfolio in predeparture sessions, continuously worked on their portfolios during the stay abroad, and completed them after they returned to Japan. The examination of submitted portfolios and interviews with the students show that the process of producing the portfolios helped them become autonomous learners and maximize their study abroad experience and opportunities.

本稿ては、著者が勤務する大学の短期海外語学研修吅がラムに、どのようにポートフオリオを構想し、組み込んだかにつ いて説明する。16名の大学生がプログラムに参加した。参加者は全員、フログラム以前にポートフオリオを作成した経駼がな かった。海外での研修内容と参加学生の分析に基づいてポー・トフォリオの構想を立てた。学生は自分の学びをその都度振り

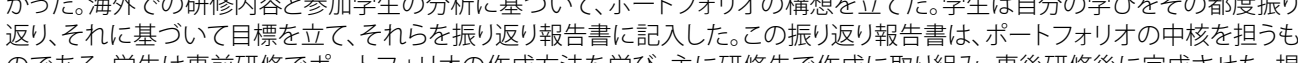
のでる。学生は事前研修で゚ーートフオリオの作成方法を学び、主に研修先て作成に取り組み、事後研修後に完成させた。提 出されれホホートフオリオと学生ヘのインタビューから、゚ートフオリオを作成することにより学生がよりよい自律的学習者とな り、短期間の海外語学研修を有意義なものにしたと感じているとが分かった。

$\checkmark$ he number of Japanese university students who study abroad for less than one month more than quadrupled between 2009 and 2017 (MEXT, 2019). Increasing numbers of Japanese universities are sending students to foreign host institutions, and credits are given for successful program completion. In spite of this, short-term studyabroad programs in English-speaking countries were not available at my university. I initiated a study-abroad program following a year of planning, considering what would make the program most effective for my students.

Host institution programs greatly vary due to a wide range of factors; likewise, the experiences of individual students tend to be different even in the same program (Engle \& Engle, 2003). At the individual level, my students in the program were affected by different factors such as their expectations for the program, their English proficiency, backgrounds, willingness to communicate with people in the host country, and learning styles. At the program level, a considerably influential factor was host families. The host families were screened based on criteria set by the host institution. One student from my school was assigned to each host family. Host families differed greatly in terms of the number of family members, their ages, personalities, occupations, hobbies, the amount of time they could spend with the students, meals they would provide for the students, and so forth. Even within the same program, different factors existed that were likely to make the students' study-abroad experiences unique. A short-term study abroad, especially for less than one month, can pass very quickly, giving students no sense of fulfillment. Thus, they need to take responsibility for their learning because every moment of their stay abroad, even outside the school, can be a learning opportunity. They cannot be with teachers and staff from the host institution or their Japanese school all the time; therefore, I sought methods to help each student do their best in the studyabroad program.

I found portfolios suitable for my students as they could help students actively participate in all aspects of their learning, if designed and implemented carefully. Delett, Barnhardt, and Kevorkian (2001) summarized the benefits of portfolios: "Portfolios provide a portrait of what students know and what they can do, offer a multidimensional perspective of student progress over time, encourage student selfreflection and participation, and link instruction and assessment" (p. 559). Portfolios are 
usually explained by three general characteristics: collection, selection, and reflection (Cummins \& Davesne, 2009; Duong, Cuc, \& Griffin, 2011; Hamp-Lyons \& Condon, 2000). Portfolios include materials that students select among the ones they collected based on their own objectives. Also, they include their reflections on what the selected materials demonstrate, in other words, what they learned. Portfolios continuously encourage students to reflect on what they have done and set goals to attain their objectives based on their reflection. Portfolios are an autonomy-based pedagogy developed in Western cultures (Pennycook, 1997; Schmenk, 2005) and learner autonomy is defined as the learners' ability to take responsibility for his or her own learning (Holec, 1981). According to Chan (2001), the principles of self-reflection and self-direction involved in producing portfolios promote autonomous learning. I believed that these principles of self-reflection and self-direction would help my students to maximize their stay abroad. Therefore, the portfolio was designed around the principles of self-reflection and self-direction. In this paper, I will describe how the portfolio project was designed and implemented for my students who participated in a short-term study-abroad program.

\section{The Short-Term Study-Abroad Program}

The overall goal of the program was to deepen the students' understanding of the target culture and improve their English skills, especially listening and speaking. The program included three phases: predeparture sessions, a 3-week study abroad in Australia, and sessions after returning to Japan. Before the departure, the students participated in four sessions to prepare them for their study abroad: the first session was for receiving the overall program information including its objectives, schedule, evaluation criteria, and the curriculum of the host institution; the second session was for learning about the target culture and crisis management; the third was for having communication training in the target language; and the fourth was for sharing their goals for the program with program members. Before the departure, students wrote a letter to their host family. During the stay abroad, on weekday mornings, they attended English lessons at a language school attached to a university. In the afternoons, they had a variety of activities outside the classroom, including taking short trips to historical places and communicating with Australian university students. The class was composed only of students from my university. Weekends were spent as freetime. Some students socialized together, and others spent time with their host family. Upon returning to Japan, students wrote a letter to their host family and completed 2-day sessions during which they reported on their study-abroad experiences.
Sixteen students participated in the program: four from the department of Japanese literature, one from the department of Chinese literature, and 11 from the department of international politics and economics. Four students were in the 1st year at university, eight in the 2nd year, three in the 3rd year, and one in the 4th year. None had studied abroad nor produced portfolios before the program. Until entering the university, they had studied English mainly in classrooms with an excessive emphasis on vocabulary, grammar, and reading comprehension. They rarely had chances for oral communication to put their knowledge and skills of English into practice. In the predeparture sessions, all showed high motivation to participate in the program. I accompanied the students as a group leader for support and to assess the program's effectiveness.

The Portfolio in the Short-Term Study-Abroad Program The Design and Implementation of the Portfolio

I designed the portfolio considering the students' characteristics and what the host institution would offer. In the predeparture sessions, the students were informed that the portfolio was an important component of the program evaluation, which consisted of evaluation by the host institution, observations of the students' participation and performance in the program by the teacher from their university, their participation and performance in the predeparture sessions and the sessions after returning to Japan, and their portfolios. Portfolios would be evaluated by how well they were completed following the specified instructions. After the students received instructions on how to produce the portfolio in the predeparture sessions, they continuously worked on their portfolios during the stay abroad. In the 2-day sessions after returning to Japan, the students reported on their study-abroad experiences, showing the relevant materials in their portfolios to the program members in English. Each student had a 20-minute presentation time, including a 15 -minute report and 5-minute question-and-answer time. Following this, their portfolios were completed and submitted.

\section{The Reflective Report in the Portfolio}

To guide the students to better work on their self-reflection and self-direction in the portfolio, I created a reflective report that was filed as part of the portfolio. Planned intervention can successfully direct students to focus on what should be learned (Cook \& Brown, 2019). The reflective report included forms specifying what and how much should be written in specified languages. It was designed to help the students reflect on what and how they were learning throughout the program. Also, it included sections 
for writing about aspects that they would like to improve and for setting goals based on reflection. Students were instructed to carefully complete the report, which is central to the portfolio, and select materials relevant to what they wrote. For example, if students wrote about enjoying their first-time experience of grocery shopping and cooking dinner with their host family in the report, they could include pictures of things they purchased at the supermarket or themselves cooking dinner, labels or packages of the purchases, the receipts of the purchases, their memo of the recipe for the dish they learned from thei host parent, and so forth. The selected materials should be relevant to the report and help students remember important moments of their study abroad. The students were instructed to file the report and selected materials in a binder; selected materials could be inserted in clear pockets.

\section{The Contents of the Reflective Repor}

The reflective report covered the three phases of the program. For the predeparture sessions, the students wrote about what they learned from the sessions and set goals that they would like to achieve in the program. For the 3-week study abroad in Australia, they kept a daily journal that was included in the reflective report. The daily journal included sections for writing about their health condition, the weather, what they ate each day, daily schedule, a diary entry, English expressions that they learned, communication with their host family, points that they improved, points that they would like to improve, and goals for the next day or the rest of the stay. After returning to Japan, the students wrote about improvements in their English proficiency (speaking, listening, reading, writing, vocabulary, and interaction), participation and performance in the morning lessons and the afternoon activities at the host institution (efforts that they made and points that they still needed to improve), communication with their host family (a description of each family member, memories of and happy moments with them, difficulties, efforts, and what they learned through the homestay experiences), what they learned about the area (history, geography, climate, tourist places, transportation, etc.), what they learned about the target culture (customs, manners, rules, taboos, values, traits of people, etc.) goals for their English learning after the program, and how they will make use of their experiences abroad in their lives.

Considerations in Creating the Forms of the Reflective Report

In order to help the students understand and clearly visualize how they were expected to complete the forms of the reflective report, examples were provided. The Appendix shows an example of the daily journal in the reflective report, which the students were expected to keep every day during the stay. The examples were carefully written so that the students could understand what, how much, and how many details they should write on the forms of the reflective report. In terms of space on the forms, Liu and Hansen (2002) pointed out that careful design is important to obtain enough information from students because they usually judge how much they are expected to write based on the given space in a writing class. To prevent the students from giving insufficient information on the forms, the minimum amount to write for each section was specified on the forms by giving sufficient space.

Students were instructed to write in the reflective report using English, their target language. However, in some sections of the daily journal, they were permitted to write in Japanese, their first language. This was done to decrease the burden that the students might feel in writing only in English considering their knowledge and skill levels, although they were able to fill in all the sections in English if they took time. The sections where Japanese use was allowed required the students' deep thinking and reflection, which is likely to call for more advanced writing skills.

In the predeparture sessions and during the stay, I suggested that the students take notes of what they did and learned on a separate piece of paper when they were too busy or tired to complete the daily journal every night, instead of leaving it uncompleted for many days. Also, I advised them not to fail to reflect on what they did and learned every night so that they could set goals for the next day or the rest of the stay based on the reflection, even on the separate piece of paper. The goal of this method was to help the students complete the daily journal based on their notes when they had time. Also, this could serve the main purpose of the daily journal, which was to promote the students' self-reflection and self-direction for their learning on a daily basis during the stay.

By What Means and How Well the Students Produced the Portfolios Three Types of Students in Terms of How They Initially Worked on the Portfolios

Once a week, three times in total during the stay, I confirmed the students' portfolio progress by viewing their work, focusing on the daily journal in the reflective report. I provided advice on how they should work depending on their progress. I found that the students varied in terms of how well they initially worked on the portfolios by themselves. They could be broadly divided into three types. 


\section{Type One: Independent Learners}

These were students who worked very well by themselves. They wrote about what they did and learned in detail, noticing even slight changes and setting specific goals every night. One salient feature of this type was their dedication to completing the daily journal. They mentioned that they spent a lot of time keeping the daily journal; therefore, they were ready to complete their daily journals with what they planned to write at night. Not all the students of this type were necessarily confident in writing in English. Those students with less confidence reported that they tried to check unknown English expressions in a dictionary or with people around them like their host family. Fewer than half of the students were this type.

Type Two: Learners Who Needed Assistance

These were students who wrote the same or similar descriptions of what they did and learned every day in the daily journal, which resulted in insufficient reflections. They failed to include detailed information; therefore, they did not reflect well enough to set specific goals for the next day or the rest of the stay. For example, one student wrote the following: "I could not respond well to my host family when they talked to me," as a point that she would like to improve. Another day she wrote, "I would like to respond well to my host family," as her goal for the next day or the rest of the stay. These sentences were repeated for 3 consecutive days and were written in Japanese (permitted in the sections). More detailed information could have been included such as feelings, in what situations she could not respond well, anything she tried to do to achieve the goal, and slight improvements in herself during the 3 days. I tried to elicit information from each student of this type by asking questions such as what, who, when, where, why, and how. In this way, they learned how they could include detailed information, reflect carefully based on the information, and set goals based on the reflection. I found that the students of this type did not have such a strategy and could be trained with advice. The proportion of this type to the total number of the students was about the same as the first type.

Type Three: Learners Who Failed to Complete the Assigned Tasks These were students who could not make any progress and thus could not complete the daily journal. Only a few of the students fell into this category. They mentioned that they enjoyed their stay and did not have energy and time for the daily journal every night, although they actively participated in the lessons and activities offered by the host institution during the day. I explained the importance of the daily journal in their learning in the program, and helped each of them complete the forms for one day so that they could understand expectations and complete it by themselves.

\section{Skills for Autonomous Learning Used in Producing the Portfolio}

An examination of the submitted portfolios showed that most of the students, the first and second types, completed the portfolios well; however, a few students, the third type could have completed the portfolios to a higher standard, especially in terms of detailed descriptions and careful reflection. What differentiates between the students appears to be whether they had the ability to notice changes, reflect on their notice of the changes, set goals based on the reflection, and put the decision into practice. This ability includes skills required for autonomous learning such as metacognitive awareness (Klenowski, Askew, \& Carnell, 2006), self-reflection (Rea, 2001), and self-direction (Chan, 2001). The students came to be able to manage their time and energy during the stay, which is also viewed as an essential skill for autonomous learning (Yang, 2003).

The students of the first type seemed to have had this ability from the beginning. Although the students of the second type did not seem to start with the ability, their autonomy increased during the stay, and the portfolios were completed well by the end. One example of the students with the ability is when a student noticed a mental change toward his fears of making mistakes. At first, he avoided saying something he thought he could not express well in English. However, some foreign students he met on campus did not seem to worry about making mistakes in English and managed to express what they wanted to say freely. He felt that he was wasting his limited time abroad due to his fears. That night, he decided not to avoid something he thought he could not say well in English. In his daily journal for the following days, I could see how he challenged himself to attain the goal. The daily journals of the students of the first two types show that they kept their goals in mind and tried to achieve the goals during the stay. The students of the third type seemed to lack this ability. They could not make any progress by themselves at the beginning. However, they developed their autonomy during the stay so that they could eventually complete and submit the portfolios.

The Students' Reactions to Producing the Portfolios

After the students submitted the portfolios, all were individually interviewed about their experiences of producing the portfolio. 


\section{The Difficulty of Securing Time and Energy}

Most students mentioned that securing time and energy for completing the daily journal every night during the stay was a challenge. They reported that they used the strategy of taking notes and then completing the daily journal later when they had time, as suggested. They found that the strategy was useful and mitigated their pressure to complete the daily journal every night.

\section{The Necessity of Supportive Learning Environment}

Many students expressed their appreciation for my confirming their progress in the portfolios and providing advice. All students of the third type, who could not make any progress by themselves at the beginning, mentioned that they could not have even finished their portfolios without my advice and encouragement during the stay. Even the students of the first type who had no problem from the beginning mentioned that my regular confirmation encouraged them to work harder. Also, they said that they enjoyed showing and explaining their progress to me. Establishing a supportive learning environment through communication between teachers and students is one of the benefits reported about portfolios (Lam \& Lee, 2010; Romova \& Andrew, 2011). Believing that the portfolio would benefit the students in the program, I designed it with a great emphasis on the reflection aspect and engaged in helping the students produce the portfolios throughout the program. Hirvela and Sweetland (2005) maintained that teachers' sustained focus on and commitment to portfolios is necessary for successful implementation of the portfolios. The teachers' attitudes will show students that value is placed on the portfolios and that they are important in their learning. Also, the attitudes will influence how well the students work on the portfolios and to what extent they can learn by doing them.

\section{The Students' Satisfaction With Their Study-Abroad Experiences}

All the students expressed their satisfaction with their study-abroad experiences and mentioned that they made the most of their opportunities to study abroad in the limited length of time. The students, especially those who completed the portfolios well, reported that they did not waste time during the stay in an unproductive and unplanned way. They attributed their fruitful experiences to the process of producing the portfolio, especially keeping the daily journal. One student said,

Without the daily journal, I wouldn't have even given a try to look back on the day every night. I wouldn't have even thought about goals for the next day or the rest of the stay. I could have enjoyed my stay there without the daily journal, but I have no doubt that it wouldn't have been as rich and dense as my experiences with it.

The students reported that the opportunity to reflect on their learning and set goals based on the reflection led to their increased metacognitive awareness. They said that they needed to examine how they were learning and know their strengths and weaknesses to complete the daily journal. The students felt that they increased their responsibility for their learning. It appears that the students benefited from producing the portfolios while perceiving improvements in their skills for autonomous learning such as self-reflection, self-direction, and metacognitive awareness.

\section{Conclusion}

In this paper, I have shown how I designed and implemented a portfolio project in a short-term study-abroad program at my university in Japan. Studies regarding portfolios in Asian contexts attributed the Asian students' unsuccessful performance in their portfolios to their lack of experience in producing them and managing their autonomous learning (Ho \& Crookall, 1995; Rea, 2001; Yang, 2003). This suggests that EFL students need training to be ready for autonomy-based pedagogies such as completing portfolios. Researchers have maintained that autonomy-based pedagogies developed and used in Western cultures need to be contextualized for EFL learners (Pennycook, 1997; Schmenk, 2005). I have shown in this paper how Japanese EFL university students completed a portfolio project without prior portfolio experience. The process of producing the portfolio helped students develop and improve their skills for autonomous learning such as self-reflection, self-direction, and metacognitive awareness. Initially, some of the students could not satisfactorily work on their daily journals with only a few making little progress by themselves. The submitted portfolios confirmed that the process of producing the portfolio helped them develop and improve their ability to notice changes, reflect on the changes, set goals based on the reflection, and put the decision into practice. This indicates that even if students are not ready for doing portfolios, they can be trained to become better autonomous learners by producing them, if the portfolios are designed and implemented carefully. The study demonstrated that whether and how well the students completed the portfolios greatly depended on how the teacher designed and implemented the portfolio project. The teacher's sustained focus on and commitment to the portfolios was found to be necessary. I hope that ideas about how I designed and implemented the portfolio project could be useful for language teachers who would like to incorporate a portfolio into a study-abroad program. 


\section{Bio Data}

Tomoka Kaneko has been reforming and developing the English curriculum at her school. She has been searching for ways to help Japanese EFL university students best benefit from language learning. She is currently interested in portfolios in a study-abroad program and peer review in a writing class.<t-kaneko@nishogakusha-u.ac.jp>

\section{References}

Chan, V. (2001). Readiness for learner autonomy: What do our learners tell us? Teaching in Higher Education, 6(4), 505-518. https://doi.org/10.1080/13562510120078045

Cook, M. \& Brown, H. (2019). Using the study abroad experience to augment preservice teachers' practicum. In P. Clements, A. Krause., \& P. Bennett (Eds.), Diversity and inclusion (pp. 95-102). Tokyo: JALT. https://doi.org/10.37546/JALTPCP2018-13

Cummins, P. W., \& Davesne, C. (2009). Using electronic portfolios for second language assessment. Modern Language Journal, 93, 848-867. https://doi.org/10.1111/j.1540-4781.2009.00977.x

Delett, J. S., Barnhardt, S., \& Kevorkian, J. A. (2001). A framework for portfolio assessment in the foreign language classroom. Foreign Language Annuals, 34(6), 559-568. https://doi.org/10.1111/j.1944-9720.2001.tb02103.x

Duong, M. T., Cuc, N. T. K., \& Griffin, P. (2011). Developing a framework to measure processoriented writing competence: A case of Vietnamese EFL students' formal portfolio assessment. RELC Journal, 42(2), 167-185. https://doi.org/10.1177/0033688211402179

Engle, L., \& Engle, J. (2003). Study abroad levels: Toward a classification of program types. Frontiers: The Interdisciplinary Journal of Study Abroad, 9, 1-20. Retrieved from https://frontiersjournal.org/

Hamp-Lyons, L., \& Condon, W. (2000). Assessing the portfolio: Principles for practice, theory, and research. Cresskill, NJ: Hampton Press.

Hirvela, A., \& Sweetland, Y. L. (2005). Two case studies of L2 writers' experiences across learningdirected portfolio contexts. Assessing Writing, 10(3), 192-213. https://doi.org/10.1016/j.asw.2005.07.001

Ho, J., \& Crookall, D. (1995). Breaking with Chinese cultural traditions: Learner autonomy in English language teaching. System, 23(2), 235-254. https://doi.org/10.1016/0346-251X(95)00011-8

Holec, H. (1981). Autonomy and foreign language learning. Oxford, England: Pergamon.

Klenowski, V., Askew, S., \& Carnell, E. (2006). Portfolios for learning, assessment and professional development in higher education. Assessment \& Evaluation in Higher Education, 31(3), 267-286. https://doi.org/10.1080/02602930500352816

Lam, R., \& Lee, I. (2010). Balancing the dual functions of portfolio assessment. ELT Journal, 64(1), 54-64. https://doi.org/10.1093/elt/ccp024
Liu, J., \& Hansen, J. G. (2002). Peer response in second language writing classrooms. Ann Arbor: The University of Michigan Press.

MEXT. (2019).「外国人留学生在籍状況調査」及び「日本人の海外留学者数」等について [Regarding “survey about registered foreign students" and "the number of Japanese who study abroad" and so forth]. Retrieved December 31, 2019, from https://www.mext.go.jp/a_menu/koutou/ryugaku/1412692. htm

Pennycook, A. (1997). Cultural alternatives and autonomy. In P. Benson \& P. Voller (Eds.), Autonomy and independence in language learning (pp. 35-53). London, England: Longman.

Rea, S. (2001). Portfolios and process writing: A practical approach. The Internet TESL Journal, 7(6). Retrieved from http://iteslj.org/Techniques/Rea-Portfolios.html

Romova, Z., \& Andrew, M. (2011). Teaching and assessing academic writing via the portfolio: Benefits for learners of English as an additional language. Assessing Writing, 16, 111-122. https://doi.org/10.1016/j.asw.2011.02.005

Schmenk, B. (2005). Globalizing learner autonomy. TESOL Quarterly, 39(1), 107-118. https://doi.org/10.2307/3588454

Yang, N.-D. (2003). Integrating portfolios into learning strategy-based instruction for EFL college students. International Review of Applied Linguistics in Language Teaching, 41(4), 293-317. https://doi.org/10.1515/iral.2003.014 
Kaneko: Ideas for Designing and Implementing Portfolios for Short-Term Study Abroad

\section{Appendix}

Example of the Daily Journal

\begin{tabular}{|c|c|c|c|}
\hline \multicolumn{2}{|l|}{$\bigcirc$ Date: } & \multicolumn{2}{|l|}{ August 20th, Tuesday } \\
\hline \multicolumn{2}{|c|}{$\bigcirc$ Health condition (in English): } & \multicolumn{2}{|l|}{ a little bit tired } \\
\hline \multicolumn{2}{|c|}{ Weather (in English): } & \multicolumn{2}{|c|}{$\begin{array}{l}\text { sunny in the morning, cloudy in the } \\
\text { afternoon, light rain at night }\end{array}$} \\
\hline \multicolumn{4}{|c|}{$\bigcirc$ What I ate today (in English): } \\
\hline Breakfast & Lunch & Dinner & In-between foods \\
\hline $\begin{array}{l}\text {-cereals with milk } \\
\text {-orange juice }\end{array}$ & $\begin{array}{l}\text {-fries (small size) } \\
\text {-a cheeseburger }\end{array}$ & $\begin{array}{l}\text {-salad } \\
\text {-spaghetti with meat } \\
\text { sauce } \\
\text {-two slices of bread }\end{array}$ & $\begin{array}{l}\text { - a can of Coca-Cola } \\
\text { - a small bag of } \\
\text { potato chips }\end{array}$ \\
\hline
\end{tabular}

\section{Time schedule of the day}

(Write about what you did today and add a description of each activity in English.)

\begin{tabular}{|l|l|}
\hline 0:00-1:00 & $\downarrow$ \\
\hline 1:00-2:00 & $\downarrow$ sleeping \\
\hline 2:00-3:00 & $\downarrow$ \\
\hline 3:00-4:00 & $\downarrow$ \\
\hline 4:00-5:00 & $\downarrow$ \\
\hline 5:00-6:00 & Sara woke me up at 6:00. \\
\hline 6:00-7:00 & I had breakfast. I prepared to go to school. \\
\hline 7:00-8:00 & I took a ferry to school. \\
\hline 8:00-9:00 & I took English lessons at school in the morning. \\
\hline 9:00-10:00 & (I learned how to give and ask for directions.) \\
\hline 10:00-11:00 & I and my friends strolled in a park near the campus. \\
\hline 11:00-12:00 & We had lunch at a hamburger shop. \\
\hline 12:00-13:00 & \\
\hline
\end{tabular}

\begin{tabular}{|l|l|}
\hline 13:00-14:00 & We went sightseeing in Mount Coot-tha. \\
\hline 14:00-15:00 & We enjoyed a great view of Brisbane. \\
\hline 15:00-16:00 & I took a ferry back home. \\
\hline 16:00-17:00 & I went grocery shopping with Fred. \\
\hline 17:00-18:00 & I helped Sara prepare dinner. \\
\hline 18:00-19:00 & I had dinner with Fred, Sara, and Maria. \\
\hline 19:00-20:00 & After dinner, we watched TV with them over a cup of tea. \\
\hline 20:00-21:00 & I took a shower. I did a stretch. \\
\hline 21:00-22:00 & I wrote in my diary. \\
\hline 22:00-23:00 & I went to bed at 22:00. \\
\hline 23:00-24:00 & $\downarrow$ \\
\hline
\end{tabular}

$\bigcirc$ Diary entry (Write in a diary in English in more than 100 words.) $\quad 117$ words

My host mother, Sara, came to my room and woke me up. I had my alarm set for 5:50, but I didn't wake up then. I didn't hear the alarm going off.

After breakfast, I took a ferry to school. I felt relaxed in the ferry today. Yesterday, I felt uneasy because I was not sure if I took a right ferry to school.

After I got back from school, I and my host father, Fred, went to a supermarket in the town. The supermarket is big and sells a variety of goods. We bought ground beef and canned tomatoes to cook spaghetti with meat sauce. It was a lot of fun to cook it with Sara.

※ English translation of the section below is given in parentheses for this paper.

$\bigcirc$ 英語表現のリスト (List of English expressions)

(今日学んだ表現や辞書で確認したものを10個以上書きましょう。)

(Write 10 English expressions or more that you learned and/or checked in a dictionary today.) 
Kaneko: Ideas for Designing and Implementing Portfolios for Short-Term Study Abroad

\begin{tabular}{|c|l|l|}
\hline & $\begin{array}{l}\text { 英語表現 } \\
\text { (English expressions) }\end{array}$ & $\begin{array}{l}\text { 日本語の意味 } \\
\text { (Meanings in Japanese) }\end{array}$ \\
\hline 例 & grocery & 食料品 \\
\hline 1 & go off & (アラーム時計が)鳴る \\
\hline 2 & fare & 運賃 \\
\hline 3 & uneasy & 不安 \\
\hline 4 & get lost & 迷子になる \\
\hline 5 & “For here or to go?” & 店内で召し上がりますか?それともお持ち帰りですか? \\
\hline 6 & by the window & 空際の \\
\hline 7 & admission fee & 入場料 \\
\hline 8 & observation deck & 展望台 \\
\hline 9 & canned & 缶詰めの \\
\hline 10 & fry & 炒める \\
\hline 11 & ground beef & 挽き肉 \\
\hline 12 & checkout counter & スーパの精算台 \\
\hline
\end{tabular}

※English translation of the section below is given in parentheses for this paper.

○ホストファミリーとの交流に関して (Communication with your host family)

(英語で3行以上書きましょう。)(Write in three or more lines in English.)

I went grocery shopping with Fred at a supermarket near the house. I helped Sara prepare dinner before she asked me to do so. I learned a lot of expressions about cooking. She was so happy that I helped her.

I watched the TV after dinner with my host family. Although it was hard for me to understand the TV show, I was just happy to be with them. ※nglish translation of the section below is given immediately after the section for this paper.

○努力した点·改善した点

(英語又は日本語で2つ以上書きましょう。)

(1) 昨日は恥ずかしくてHasson先生に「おはようございます。」と自分から言えなかっ たが、今日は自分から元気に挨拶をすることが出来て嬉しかった。

\section{(2) 午後の観光では、オーストラリア人のツアーガイドに積極的に質問をした。親切に} 詳しく答えてくれた。

\section{Points that I improved}

(Write two or more points in either English or Japanese.)

(1) I was too shy to say, "good morning" to Ms. Hasson until she said it to me yesterday. However, I am happy that I could say it cheerfully before she said it to me today.

(2) I asked an Australian tour guide questions in the afternoon sightseeing. She was kind enough to answer all my questions.

※English translation of the section below is given immediately after the section for this paper.

$\bigcirc$ 反省点・改善が必要な点

(英語又は日本語で2つ以上書きましょう。)

(1) ホストファミリーが言っていることを理解できなくても、分かっているふりをしてしまった。理解 できるまで、聞き返すべきであった。

(2)アラームをセットしたが、自分では起きることが出来なかった。Saraが起こしてくれた。 


\section{$\bigcirc$ Points that I would like to improve}

(Write two or more points in either English or Japanese.)

(1) I pretended that I understood what my host family said. I should have asked them to repeat it until I could understand it.

(2) I had my alarm set; however, I couldn't get up by myself. Sara woke me up.

※English translation of the section below is given immediately after the section for this paper.

\section{○明日又は今後の目標}

(英語又は日本語で2つ以上書きましょう。)

(1) 言っていることが分からない時は、理解できるまで聞き返して適切な反応をしたい。 すらすら言えなくてもいいので、自分の意見を伝える努力をしたい。 (2) Saraに起こしてもらうのではなく、自分で起きて、朝食の準備を手伝いたい。

\section{Goals for tomorrow or the rest of the stay}

(Write two or more goals in either English or Japanese.)

(1) When I can't understand what a speaker says, I would like to ask him or her to repeat it until I can understand it. In this way, I will hopefully respond to him or her well and appropriately. I would like to express my opinions even if I can't do it smoothly. (2) Instead of troubling Sara to wake me up, I would like to get up by myself and help her prepare breakfast. 